\title{
Getting invasive species on the political agenda: agenda setting and policy formulation in the case of ash dieback in the UK
}

\author{
Heather Mackay • E. Carina H. Keskitalo • Maria Pettersson
}

Received: 2 March 2016/Accepted: 14 March 2017/Published online: 1 April 2017

(C) The Author(s) 2017. This article is an open access publication

\begin{abstract}
This study reviews how the issue of ash dieback has been placed on the political agenda in the UK, a country where the disease has affected one of the largest national extents, thus representing a particularly severe case. Comparisons are made between how the scientific community framed the ash dieback threat and the resulting response strategy and how both the media and the British government framed the problem. Representing one example of media framing, the study analyses one British newspaper's coverage of the disease and the response strategies (the Daily Telegraph). The analysis highlights a gap between the biologically rooted perspective and the perspective of policymakers, where policy must manoeuvre between disparate viewpoints and needs. Crucially, none of Pautasso et al.'s (Biol Conserv 158:37-49, 2013) five plant-science-based solutions were explicitly adopted by the British Government in their response strategy to ash dieback disease. The same is true of the biological control recommendations offered by Kirisits et al. (J Agric Ext Rural Dev 4(9):230-235, 2012). Instead, the
\end{abstract}

H. Mackay · E. C. H. Keskitalo $(\bowtie) \cdot$ M. Pettersson Department of Geography and Economic History, Umeå University, Umeå, Sweden

e-mail: Carina.Keskitalo@umu.se

M. Pettersson

Department of Business Administration, Technology and Social Sciences, Luleå University of Technology, Luleå, Sweden government adopted a broader, more comprehensive approach than that recommended by plant scientists. The present analysis thus provides an example of a holistic perspective on the multiple competing factors that policymakers must navigate in their attempts to delineate action. It highlights instances in which proposed biological responses were rendered less applicable by a failure to understand the agendasetting process and the policy-making arena. The present findings suggest that an improved understanding of the factors influencing agenda setting and policy action is essential to arriving at a more effective and integrated understanding of responses to biological threats.

Keywords Invasive species - Ash dieback - UK · Framing $\cdot$ Agenda-setting $\cdot$ Policy

\section{Introduction and aim}

There is acknowledgement that regulations on plant trade need to be reformed (e.g., Santini et al. 2013). The urgent need for action has been expressed by a large number of plant health scientists, for example in the Montesclaros Declaration. This is a joint declaration made by a group of international scientists who proposed "a phasing out of all trade in plants and plant products determined to be of high risk to forested ecosystems but low overall economic benefit" 
(Montesclaros 2011: 1). The dieback of European ash (Fraxinus excelsior), caused by the ascomycete Hymenoscyphus pseudoalbidus (anamorph Chalara fraxinea), constitutes an example of the growing scale and implications of plant pests and diseases. The disease has emerged in 22 European countries (by 2010), since its discovery in 1992 in Poland. "The gradual expansion and high intensity of the ash dieback epidemic in Europe may suggest that $H$. pseudoalbidus is an invasive alien organism" (Timmermann et al. 2011: 14; cf. Bakys et al. 2009). Concurrent developments, such as climate change and increasing globalization, will likely result in similar invasive species occurrences becoming more common, both as natural conditions change and as trade increases (Pautasso et al. 2013).

However, the logic of the international trade system at large, under which plant health trade is encompassed, largely prevents solutions such as phasing out trade in plants. Thus far, regulating invasive species has been relatively difficult, as the need for action against specific species has to be clearly and highly evident, and implementation measures must be designed in order not to infringe upon trade agreements under the WTO General Agreement on Tariffs and Trade (GATT). They must also comply with the Agreement on the Application of Sanitary and Phytosanitary Measures (the SPS-agreement) (cf., e.g., Pettersson et al. 2016). This has meant that EU member states are constrained to act unilaterally on invasive species. In addition, there is also a great difference in how political systems, as opposed to the natural sciences, manage crisis. The logic in the natural sciences largely focuses on the problem per se (such as the Montesclaros Declaration) or on technical/scientific management of it [such as the measures suggested by Pautasso et al. (2013), specifically regarding ash dieback]. In contrast, policy systems are largely dependent on being able to develop solutions that are acceptable to several groups, both in relation to what resources are spent on and in relation to other competing needs. In order to get an issue on the political agenda in a manner that makes decision-makers pay attention, a policy context needs to exist that enables the specific issueto be clearly raised. This elevation of the issue in the "policy queue" is often the result of a crisis, which thus legitimates the attention then allocated (e.g., Kingdon 1995).
The present study reviews how the issue of ash dieback has been placed on the political agenda in the UK. Britain is a country where the disease has had particularly widespread impact and where its impact has been the subject of considerable public concern. Given the legal limitations for acting on issues of invasive species described above, the paper also discusses the possibilities for legislative action in relation to the suggestions offered in various biological assessments of requirements for containment (in particular Pautasso et al. 2013 and Kirisits et al. 2012). These containment strategies include suggestions to "[b]an the trade of ash nursery seedlings from areas already infected" (Pautasso et al. 2013: 45). The article further reviews the extent to which such suggestions have been mirrored within national policy development.

\section{Theoretical framework}

A great deal of the research on invasive species and plant pests is focused primarily on ecological and biological implications and actions (see, e.g., Pautasso et al. 2012; Kirisits et al. 2012; Hantula et al. 2014). Any attempts to include a social science perspective are often limited to conducting a stakeholder survey or stakeholder communication exercises. This is not specific to the research on plant pests, but also applies to the natural sciences arena more generally, for instance within climate change debates (e.g., IPCC 2014). The broader systemic, legislative and political analytical role of social science tools and methodologies is often over-looked, resulting in prevention strategies being advocated in ignorance of many of the socio-political parameters that could have improved the chances of successful action/policy. Pautasso et al. (2012), for instance, noted in their review that "research on climate change and plant health needs to reflect the variety of levels affected and the many viewpoints involved and tools available, from the molecular to the landscape scale, using network theory, meta- and risk analysis, in collaboration with various stakeholders, the publics and scientists outside plant health science" (Pautasso et al. 2012). Pautasso et al. (2013) also specifically suggested a number of policy and management measures to contain and reduce ash dieback (Table 1), but focused in particular on more technical/scientific types of measures. 
Table 1 Summary of proposed measures to reduce the threat posed by common ash dieback to $F$. excelsior and its associated biodiversity. Modified from (Kirisits et al. 2012), reproduced from (Pautasso et al. 2013)

\begin{tabular}{lc}
\hline Option & Explanation \\
\hline $\begin{array}{l}\text { Quarantine for ash nursery } \\
\text { seedlings }\end{array}$ & $\begin{array}{c}\text { Ban the trade of ash nursery seedlings from areas already infected (plant passporting and } \\
\text { certification schemes are difficult due to latent infections) }\end{array}$ \\
$\begin{array}{c}\text { Avoid planting of ash in forests } \\
\text { and landscapes }\end{array}$ & $\begin{array}{c}\text { Planting of infected ash seedlings in forests is likely to have contributed to the rapid spread of } \\
\text { the pathogen. Increased ash tree density in the open landscape might provide stepping stones } \\
\text { for the pathogen }\end{array}$ \\
$\begin{array}{c}\text { Do not remove ash trees from } \\
\text { forests }\end{array}$ & $\begin{array}{c}\text { The chance should be given to resistant or tolerant ash trees to show this feature, so as to make a } \\
\text { breeding for resistance/tolerance programme possible. Deadwood is an essential resource for saproxylic organisms } \\
\text { Make use of the knowledge of common ash genetic diversity to start a breeding programme for } \\
\text { resistance/tolerance to the pathogen that will preserve the existing genetic diversity of the host } \\
\text { Removing as leaves in autumn around solitary ash trees may help reduce inoculum and thus } \\
\text { preserve this important heritage } \\
\text { ash trees }\end{array}$ \\
\hline
\end{tabular}

In contrast, much of the political science-related literature instead emphasizes that the types of actions that can be taken in response to a crisis largely relate to what the political situation and existing policies are. The existence of documents such as the Montesclaros Declaration or the potential items suggested by Pautasso et al. (2013) or Kirisits et al. (2012) is thus, to the extent these documents come to the attention of policymakers, one potential input into such decisionmaking dynamics. To describe the type of situation under which decisions, e.g. on prioritizing a specific item such as plant health, are taken forward, the terms agenda setting and framing are often used. Agenda setting indicates the process by which a situation or condition becomes framed or understood as a problem and is, thereby, placed on the active decision-making agenda (Kingdon 1995: 3). This often occurs through a process whereby policy entrepreneurs (policymakers, interest groups, media or other public figures who are able to credibly influence the policy-making process) are able to focus considerable attention on a specific issue. This may occur as the result of a "focusing event" such as a crisis, a change in existing accepted indicators or the personal experiences of major policymakers. It may be new reports or technologies that raise awareness. Alternatively, proposals linked to established policy and in accordance with existing values and budgetary conditions may enable a reemphasis on certain problems. Finally, political elections or changes in administration or in the public mood can be used to highlight specific problems and thus help set the agenda (Kingdon 1995; cf. Birkland
1998; Farley et al. 2008; Olsson 2009). Henstra (2010: 248) noted that in particular "emergencies and disasters are the quintessential focusing events. The level of public interest in emergency management can shift dramatically following a major emergency, because an emergency (temporarily) alters peoples' perceived vulnerability to hazards". In light of public communication and interest in showing responsiveness to, for instance, perceived plight, much of the agenda setting may be played out and reported in the media (Baumgartner and Jones 1993; Eustis 2000; Birkland 1998; Farley et al. 2008; Soroka 2002).

Framing is a specific important component of this process of agenda setting. If a problem is to be understood in a certain way, it has to be framed, i.e. linked and explained in specific ways and in relation to terms that ensure this understanding. Thus, the problem of invasive species could be understood in a variety of ways, from being mainly a technical issue, where improvement in existing routines could be a sufficient combative strategy, to being a much broader issue requiring significant institutional change, perhaps even at the World Trade Organization (WTO) level, for example in tackling climate change. Linking an issue to other crucial topics of the day, such as climate change, could raise the issue's profile, whilst linking it only to invasive species, of which politicians may have little knowledge, may lower the issue on the agenda.

This process of framing-which is used by the multiple actors involved in agenda setting as well as in other political processes-is crucially important, 
because competition continuously exists between the multiple potential problems to be taken up in policy, and because any new issue competes with multiple established issues, such as education, health care and jobs. Through the types of processes described above, an issue is lifted and framed as an issue of urgency. Whether it is taken up depends not only on framing, but also on which actors, which political context, and which trigger events become involved (the broader context of agenda setting). Framing, nevertheless, is crucially important, because the way the problem is framed will also have implications for which solutions can be proposed (e.g., whether only technical or also institutional or more holistic approaches are advocated). It has been suggested that media play a crucial role in this type of framing: framing supplies "the central organizing idea for news content that supplies a context and suggests what the issue is through the use of selection, emphasis, exclusion, and elaboration" (Tankard et al. 1991 quoted in Weaver 2007: 143). Similarly, "to frame is to select some aspects of a perceived reality and make them more salient ... in such a way as to promote a particular problem definition, causal interpretation, moral evaluation, and/or treatment recommendation for the item described" (Entman 1993 quoted in Weaver 2007: 143, italics in original; see also Reese 2007; Zhou and Moy 2007).

Media may thus be the arena in which final policy formulations with regard to high-profile events are reported when decisions have been made, making not only policy but also media actors important players in influencing public opinion. Policy formulation, taking place following successful agenda setting, involves developing acceptable courses of action for dealing with the problem, potentially choosing amongst competing problem formulations or framings (López-Santana 2006; Fifer and Orr 2013). However, the linkages between the media framing and the political framing, as well as public framings of issues, are not a given. For instance, "sources frame topics to make information interesting and palatable to journalists, whom they need to communicate information to wider publics, and journalists cannot not frame topics because they need sources' frames to make news, inevitably adding or even superimposing their own frames in the process" (D'Angelo and Kuypers 2010: 1). For an issue such as ash dieback, major events could potentially mobilize the public and media, support certain framings of an issue and eventually lead to policy change. It is thus of crucial importance to review both how the media and policy actors frame an issue and how these framings eventually may lead to or support specific policy changes, in relation to events, existing policy and political context. This process can be traced in particular through media as well as policy documents, and the present paper demonstrates such an approach and its value using ash dieback disease as an example.

\section{Materials and methods}

To review the development of agenda setting as well as the ultimate policy formulation to address ash dieback disease in the UK, the present study analysed scientific proposals, reviewed government policy documents $^{1}$ and conducted an explorative media content analysis.

To enable a comparison with specific plant-sciencebased proposals, governmental policy development during the period was reviewed and the specific suggestions for actions identified. Moreover, a timeline for agenda setting on ash dieback in the UK was constructed utilizing government reports, the goal being to identify the approximate time during which agenda setting and policy formulation on $C$. fraxinea were being developed as a guideline for the media analysis. Legislation at the EU level was also reviewed to clarify the extent of containment possible under applicable law, including international agreements. This clarifies the essential conditions to which policy formulation must be related, and thus the available framework for action. Chalara fraxinea is a complex case for which applicable regulation exists also at the EU level, thus limiting what could be done at the national level.

The process of media framing and agenda setting is illustrated through media content analysis of the British daily newspaper the Daily Telegraph, as an example of coverage during the period of the development of ash dieback. Articles were retrieved using

\footnotetext{
${ }^{1}$ Mainly Defra's Interim Chalara Control Plan (Defra 2012a), the Chalara Management Plan (Defra 2013a) and Chalara in Ash Trees: A framework for assessing ecosystem impacts and appraising options (Defra 2013b) as well as government statements on the topic.
} 
the search term "ash dieback" (cf. Wei et al. submitted). Given that this material was limited to a single newspaper, due to a combination of personnel and resource constraints and the accessibility of media material, ${ }^{2}$ the data are relatively limited and should be seen as indicative and preliminary, but nevertheless relevant in illustrating the techniques and arguments that may impact agenda setting. The resultant media material comprised 74 articles spanning from 9 June 2012 (around the time when the first media announcements we made that the disease $C$. fraxinea had been discovered in the UK) to 7 June 2014 (the time the research began).

All data were manually coded by a single coder using an inductive, issue-specific and text-based categorization (cf. Chong and Druckman 2007; Zhou and Moy 2007; Matthes 2009). An intersubjective reading of the codes is supported by quotation in the results part (Lukka and Modell 2010); in addition, the preliminary coding document was reviewed by another author in the group to cross-check the interpretation. The codes used were: (1) framing/motivation (regarding how the issue was framed and the problem motivated and discussed); (2) triggers (what events or triggers occurred that garnered attention); (3) policy entrepreneurs (what individuals or organizations, including the newspaper article authors, were involved in raising awareness of ash dieback disease); (4) feasible/not-feasible policies (what policies were presented as feasible or not feasible over time, how were the actions and/or policy solutions perceived by stakeholders and the media, and why were they perceived in this manner); (5) political changes (what political changes were made, seen as supporting the issue, or seen as being needed); (6) actions/solutions or policy proposals (what actions, policies or solutions were advocated). The solutions under this last point were further coded P1 to P6 with P1-P5 referring to the plant-science-based strategies proposed by Kirisits et al. (2012) and Pautasso et al. (2013): P1—quarantine for ash nursery seedlings; P2-avoiding planting of ash in forests and landscapes: P3-avoiding removal of ash trees from forests; P4-breeding for resistance/tolerance; $\mathrm{P} 5$-inoculum reduction around ancient ash trees; P6-any other actions, solutions or

\footnotetext{
2 The Daily Telegraph articles were easily accessible using an online search engine.
}

policies proposed. ${ }^{3}$ Such coding and content analysis allowed examination of the issue framing, or motivation, of the ash dieback problem i.e. how the problem was portrayed within the analysed media content over time; it also enabled assessment of trends and trajectories in perspectives, actions and actors. The specific newspaper articles cited are referred to by author name and publication date in the text, or if no author is listed for the piece with newspaper name; to not make the reference list too extensive, all of these can be found through the Telegraph search feature listed in the references.

\section{Results}

Triggers for attention and problem framing: the role of the Chalara invasion event

The ash dieback fungal disease, also known as $C$. fraxinea, was first found in February 2012 during a routine inspection of a nursery in Buckinghamshire, England (Daily Telegraph 2012a; Rowley 2012). "Officials say the disease is a "serious concern" in Britain after symptoms were found in a consignment of 2000 young trees imported from Holland by a nursery" (Daily Telegraph 2012a). The nursery had actually imported the trees in November 2011 and had already sold some of its stock "by mail order to 90 different gardeners and firms nationwide" (Daily Telegraph 2012a). By 26 September 2012 Louise Gray, the Daily Telegraph's Environment Correspondent and one of the newspaper's most prolific writers on the disease, reported that the fungus had been found in "six nurseries and four planting sites in England and Scotland" (Gray 2012a). However, the major piece of news that really raised concern among stakeholders, as well as the public, involved reports that the disease had been found in mature woodland in East Anglia (Gray $2012 b, n)$ and was thus not confined to nursery saplings or recent plantings.

The Telegraph's coverage, almost from the outset, likened the disease to the historic experience of Dutch Elm Disease (Gray 2012a) and referred to the $90 \%$ mortality rate among ash trees in Denmark hit by the disease (Lean 2012). Lean (2012) referred to ash

\footnotetext{
${ }^{3}$ Analysis of government policy documents used this same coding.
} 
dieback as "the worst blight to hit the countryside since Dutch elm disease".

In terms of trigger events that focused attention, the discovery of the disease's presence within the UK was the first; the realization that it was already in mature trees outside of nursery environments was the second. Additional trigger events were not necessary to sustain attention or found in the data. The remaining media coverage and interest rather depicted the growing scale and spread of infection throughout the country, as well as some emotive concern about diseaseresponse actions which saw 100,000 ash trees destroyed (Mason 2012). Calls for a compulsory ban on ash imports and decisive action to contain the disease were already clear from the non-profit woodland stakeholders in September 2012: "Without a compulsory ban on imports, ash dieback could become the new Dutch elm disease, causing widespread destruction of one of the country's most common native broadleaf trees, the [Woodland] trust said" (Gray 2012a). The Woodland Trust went on to warn of the serious environmental and financial implications of inaction: "If the disease takes hold the cost and safety implications regarding the removal of infected ash trees would be huge" (ibid.). The Horticultural Trades Association (HTA) was quick to point out that they had raised concerns about the disease back in 2009, 3 years previous to its discovery, and had requested import limitation action, but they were "told quarantine action could not be taken because the disease was already present and widespread in the UK" (Gray 2012a). Experts worried that any action taken would already "be little too late as the disease may already be widespread in private woodland and gardens, where owners do not have the expertise to spot the fungus" (Gray 2012b).

Initial response to the widespread announcement of disease presence by the Forestry Commission, the Government's Environment Secretary and through media coverage was to conduct extensive site surveys: "more than 1000 sites around the UK are now being investigated for signs of the Chalara fraxinea fungus" (Gray 2012m). Tackling such trends through better labelling and plant paper trails was suggested as a course of action by the government, but had cost implications: "Government scientists at the Food and Environment Research Agency are also advising that all plants should be issued with "passports" to show they have been inspected and are disease free. The measure would make potted plants more expensive because nurseries would have to meet the cost of the inspections" (Swinford et al. 2012; Gray 2012d), which also led to some discussion on the need to breed for increasing tree resistance (e.g., Rowley 2012). Serving to highlight the seriousness with which the government and relevant stakeholders viewed the threat from ash dieback disease to "Britain's 80 million ash trees" (Gray 2012o), and crystallising attention, was the emergency Cobra meeting (COBRA meaning Cabinet Office Briefing Room A) held on 1 November 2012 to discuss disease response strategies. Such meetings are usually reserved for matters of emergency or national security (Swinford et al. 2012). The opposition Labour party's shadow Environment Minister Mary Creagh noted that the government had been too slow to act, and that funding cuts to the Forestry Commission were crippling the country's ability to respond to tree disease threats (Gray and Collins 2012); however, a Defra spokesperson said that "a ban on trade of ash trees was not introduced sooner because scientific understanding of the disease only became apparent in 2010, by which time other tree pests such as Asian longhorn beetle were deemed to be of higher risk" (Gray 2012n) (see Fig. 1 for a summary of key events in how the actions on the disease played out).

\section{Actions and policy response}

Discussion regarding appropriate, practical and most effective ways of responding to the disease generated much coverage in the Telegraph, with responses quickly moving away from suggestions to cut down, burn or otherwise destroy large numbers of ash trees (which was a common response in the 1970s to Dutch Elm Disease). Policy was relatively quick to recognize the value in leaving affected mature ash trees to fight the disease themselves and either win (if resistant) or slowly die off: "Experts say [ash] specimens should be allowed to live as they are still good for wildlife and can be used for fuel" (Gray 2012h). Mr. Paterson, the then Environment Secretary, confirmed they would not take action against infected mature trees as "They were too 'valuable' to Britain's wildlife, mature trees take a significant amount of time to die and old ash will provide valuable evidence for scientists to study to potentially find 'genetic strains that might be resistant 


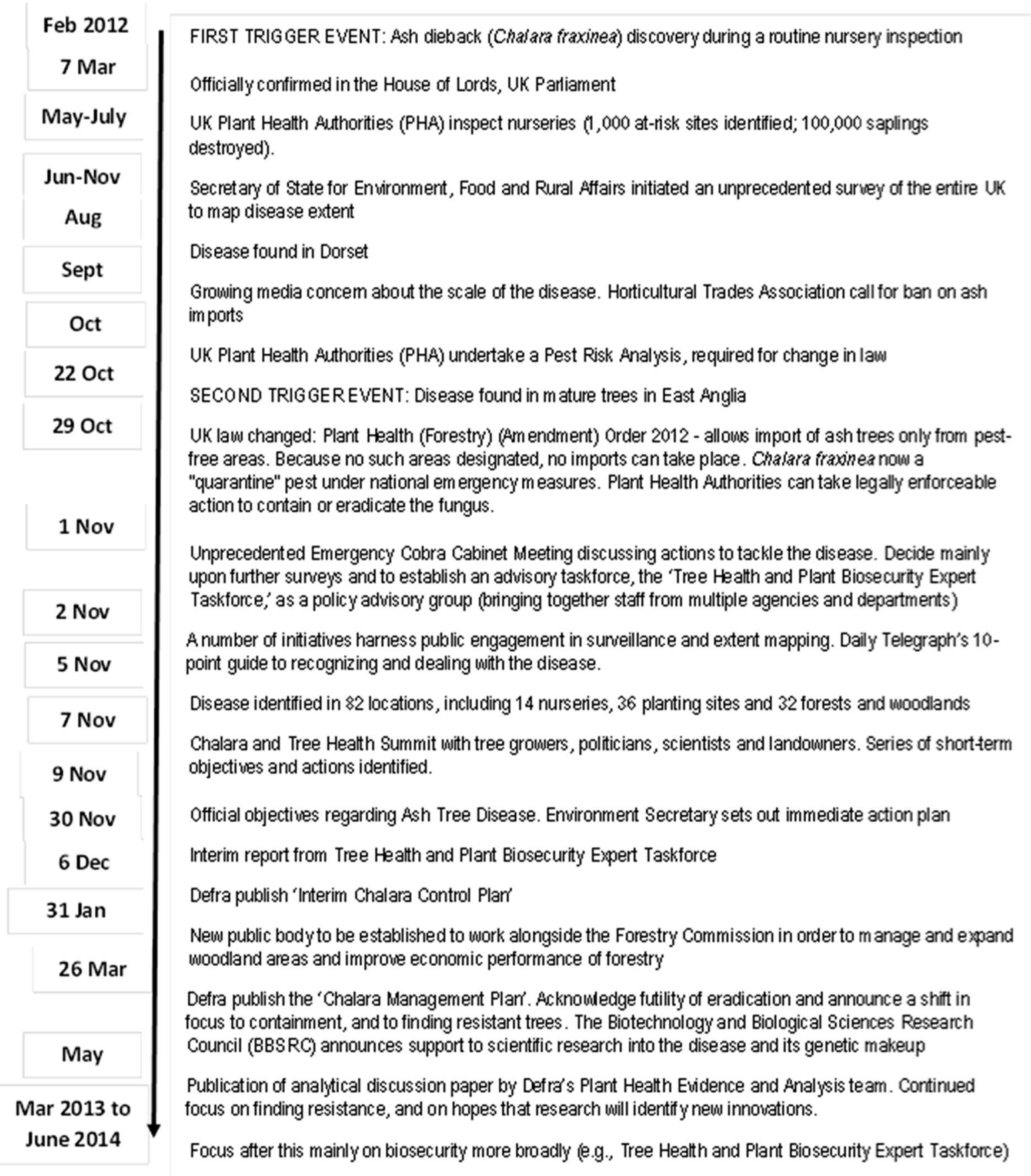

Fig. 1 Ash dieback timeline of events in Britain (June 2012-June 2014)

to the disease"" (reported in Hough 2012). Austin Brady of the Woodland Trust was reported saying "There is no evidence that large-scale felling of mature ash trees is an effective means of preventing the spread of ash dieback. 'Ill-considered felling could do more harm than good by removing resistant trees which could hold the key to the survival of the species in the UK" "(Gray 2013b). 


\section{Government's priority policy objectives}

The government clearly outlined the four main objectives guiding their policy and action response to ash dieback disease in their interim Action Plan as being to: (1) reduce the rate of spread of the disease; (2) develop resistance to the disease in the native ash tree population; (3) encourage landowner, citizen and industry engagement in surveillance, monitoring and action in tackling the problem; (4) build economic and environmental resilience in woodlands and in associated industries (Defra 2012a). These priorities guided their intervention approach. Below are described the numerous different contexts and associated framings (suggestions for problems as well as associated solutions) that were proposed.

\section{Import ban}

The government received considerable criticism for failing to ban the importation of ash trees and seedlings prior to 29 Oct 2012, when it finally took this action (Moreton 2012; Gray 2012k). During this delay between disease discovery in February 2012 and import ban in October, hundreds of thousands of ash had been imported. Customers who bought ash trees often did not know whether their seedling had been imported "since nurseries do not label if saplings have been "grown on" abroad" (Gray 2012j). Grant Murray of Alba Trees nursery and spokesman for the forestry body Confor was reported to have lamented this failure, claiming it was a major contributor to the disease presence in the UK (though as earlier noted this point is much debated): "We have been lobbying for a ban on all imports of all trees for years," he said. "Imports of ash should have been stopped at least five years ago. The fact that it [the disease outbreak] happened was because the trade continued to be allowed to import so it was almost inevitable" (Gray 2012k). Government response to the criticism included a review conducted by members of the House of Commons Environment, Food and Rural Affairs Committee, which concluded that "experts reacted slowly to the detection of ash dieback in Britain because they were too busy trying to stamp out dozens of other outbreaks and did not have enough experts available" (reported in Collins 2012a, on 11 Dec). He went on to report on scientific staff limitations describing how "Prof Ian Boyd, chief scientist at the Environment department (Defra), added: 'The tree health expert group had identified up to 28 different pathogens threatening our shores and the amount of evidence required to deliver a pest risk assessment on all of those is immense" (Collins 2012a).

Thus, the government's first serious policy response to the threat from $C$. fraxinea fungal disease in ash trees was to ban the importation of ash trees on 29 October 2012, eight months after the disease was first discovered in the country (The National Archives 2012). Although the import ban was broadly welcomed, there were "fears that the ban has been imposed too late after the government held a lengthy consultation over the summer" (Gray 2012m). The initial response strategies implemented by the Forestry Commission consisted of either cutting down or burning affected ash trees in an attempt to contain the disease (Swinford 2012c). Later, on 9 Nov 2012, the British government announced its objectives for 'Action on Ash Tree Disease Chalara' (UK Government 2012). In this "officials admitted that ash dieback will not be "possible to eradicate"' and they confirmed that mature trees affected by the fungus would not be destroyed (Hough 2012). Both the National Trust and the Woodland Trust were reported as questioning the wisdom of stating so early that the disease could not be eradicated: "Dr Simon Pryor, director of natural environment at the [National] Trust, said: 'Given our limited understanding of this disease in this country, we believe we should keep an open mind as to whether it may be possible to eradicate it, or at least contain it within the core area in the east. Even if we only delay the spread of the disease this will buy us valuable time to establish the next generation of trees and also investigate other means of increasing resistance of mature trees. "This is a major new national disaster for our countryside and it will require new resources to tackle it effectively." (Hough 2012). Here, suggestions were also provided that echoed those in plant science. Francis Fulford, Southwest England chairman of Confor, suggested: "If we are to be serious about the biosecurity of these islands then we need a blanket ban on the import of all trees and horticultural plants" (quoted in Gray 2012k).

The response from environmental organizations became more combative after the government's release of the Chalara Management Plan on $6 \mathrm{Dec}$ 2012: "In a strongly-worded critique of the new 
strategy, announced on Thursday, the National Trust accused ministers of doing "far too little, too late" to stop the disease spreading across Britain" (Collins 2012b). Dr. Simon Pryor from the National Trust was quoted saying "The limited actions and weak commitments set out in the plan will not be enough to achieve the aim of controlling the spread of the disease. It is far too little, too late. Through this Action Plan we're effectively surrendering the British landscape to this disease before we've fully investigated ways of reducing rate of spread and buying time" (Collins 2012b). Nick Collins (ibid.) elaborated: "Environmentalists said the plan focused too much on developing resistance to the disease and not enough on stopping it from spreading, and accused ministers of penny-pinching." Interestingly, industry representatives remained supportive of the government's strategy: "Harry Cotterell, president of the Country Land and Business Association, said: 'Mr Paterson is right not to rush into unnecessary expensive control measures before the chances of success have been properly evaluated"' (quoted in Collins 2012b). Duffin (2013) claimed the Management Plan had been "welcomed by experts".

Further tightening disease controls in the hopes of reducing future vulnerability in British plant and tree species, the government Environment Secretary, Mr. Owen Paterson, announced on 16 Jan 2013 plans that "all imports of oak, ash, sweet chestnut and plane trees must travel with documents showing where they are from original" (Daily Telegraph 2013); this was described as a tree paper trail. The National Trust responded positively "This is a very welcome move, and exactly the sort of action that is needed to prevent more tree pests and diseases being imported into this country" (quoted in Daily Telegraph 2013).

Yet by March 2013 Louise Gray, Telegraph Environment Correspondent, claimed that "tree experts and landowners fear it [the management plan] will focus on simply managing the decline rather than stopping the 'devastation' of Britain's woodland. They claim it has been watered down from an 'action plan' to stop the disease to a 'management plan' to keep damage to a minimum" (Gray 2013b). There appeared to be anger from some quarters at the perception that the government was making no effort to find a cure for the disease or a chemical treatment (e.g., Gray 2013b).

\section{Trade regulation considerations}

Some stakeholders pointed a finger of blame at European trading regulations, and at other countries' failures to enforce disease control regulation (ibid.). Robin Maynard, campaigns director for the Countryside Restoration Trust, supported this view and "blamed the globalisation of the plant trade that is bringing in new diseases from abroad" (Gray 2012l) and the lack of resources allocated to monitoring and border biosecurity: "The horticultural trade has increased massively but inspection and biosecurity measures have not" (Gray 20121). Academics such as Prof. Michael Shaw, University of Reading, highlighted the resource problem, claiming that funding for research and training had declined: "We have had more invasions in the last ten years than in the previous century at the same time that staff and students [of plant pathology] at universities have been falling" (Gray 20121). Germaine Greer (well-known academic, journalist, feminist), however, pointed out that we are not "entitled to blockade a perfectly legal intraEuropean trade in the absence of firm scientific information" (Greer 2012). Bunny Guinness, celebrity landscape designer and journalist, added her voice to the debate, calling for more effective border checking of plants within Europe: "But when I am working in places such as Japan, anything I import from Europe is vigorously screened. All plants have to be totally free of compost, with their roots well washed, before they are allowed in. They often spend days being checked at Sapporo after a long trip. Conversely, unloading a Dutch container lorry stashed with plants in compost, takes mere hours and the checks are probably cursory" (Guinness 2012). She went on to claim "if we enforced plant health regulations like they do in New Zealand and Japan, we would give British nurseries a boost and protect ourselves more from diseases swiftly winging their way towards us" (ibid.) (see Box 1 for a clarification of the legal situation).

The design of the EU plant health regime as an open system, in which movement into and within the Union is basically allowed on condition that the explicit restrictions and requirement be complied with, thus emphasizes the importance of supporting the system based on free trade. The system, however, has had significant drawbacks, most prominently regarding its inability to control the increasing influx of harmful organisms as a result of globalization of trade, and the European 
Box 1 Limitations due to the legal situation. Revised from Pettersson et al. (2016)

Legal protection against introduction of harmful organisms, such as the $C$. fraxinea, in the EU is provided by Directive 2000/29/EC;
the so-called Plant Health Directive. The Directive is a consolidated version of the 1976 Plant Health Directive (77/93/EEC),
including subsequent amendments to that legislation; it also reflects international trade agreements in the area. The current EU plant
health regime is a complex system that builds on the original intra-community trade, as well as Third Country imports of plants and
plant products. The main objective of the regime is to prevent entry and spread of foreign pests by means of legal instruments:
prohibition/banning and certification. The regime is based on the listing of harmful organisms (defined as pests of plants or of plant
products, which belong to the animal or plant kingdoms, or which are viruses, mycoplasmas or other pathogens) in different
categories, from particularly harmful organisms whose introduction and spread must be banned by all Member States (MS), to
plants and plant products that must be subject to a plant health inspection, including special rules for protected zones (Annex I-VI,
Directive 2000/29/EC, see also MacLeod et al. 2010)

Commission has therefore submitted a proposal for a new Regulation concerning protective measures against pests of plants (COM(2013) 267 final). The proposal contains potentially important differences compared to Directive 2000/29/EC. Schematically, pests are divided into three categories under the proposed Regulation: non-listed pests, quality pests and quarantine pests, where the latter is the main target for the Regulation. In addition to the implementing acts, MS are given some leeway in terms of possibilities of adopting additional or stricter measures. To ensure effective action against pests that are not qualified as Union quarantine pests, MS may take protective measures against the pests if they consider the criteria for EU quarantine pests fulfilled. Under certain conditions, MS should also "be allowed to adopt more stringent ratification measures than required by Union legislation" (proposed Art. (19) 2013/0114 (COD)). Provided, however, that these measures do not conflict with the free movement of, e.g., plants. Furthermore, the proposed Regulation obliges anyone who is aware of the presence of a quarantine pest to notify the competent authorities; it encourages MS to conduct surveys for the presence of pests; and it sets out ratification measures, including area restrictions, as well as rules for the establishment of contingency and ratification plans (proposed Art. (11), (14), (16) 2013/0114 (COD)). While the proposed Regulation indeed appears to offer a more preventive system, it is difficult to assess the full consequences of the proposal at this stage (see, e.g., Pettersson et al. 2015), and what possibilities the UK has to regulate $C$. fraxinea at the state level.

\section{Plant documentation}

Continuing with this theme on regulation in response to external risks, the Telegraph reported on 16 January
2013 that UK Environment Secretary, Owen Paterson, is pushing through new requirements for complete documentation of where saplings have been before they can be imported to the UK: "Owen Paterson, the Environment Secretary, has ordered that all imports of oak, ash, sweet chestnut and plane trees must travel with documents showing where they are from originally. This will allow plant health inspectors to target their inspections and to track saplings if there are any suspicions that they carry a pest or disease" (Daily Telegraph 2013). As reported he elaborated "We need to ensure we have a healthy, thriving stock of our native trees and these controls will significantly help us to prevent pests and diseases from getting established in the first place. We have learnt from ash dieback how important it is to be able to act quickly to identify where infected trees may be" (ibid.).

\section{Research funding/resistance hopes}

On 10 February 2013, Richard Gray, Science Correspondent, reported on a new early warning system developed by the crop research company Syngenta, which may help to detect plant diseases carried by the wind (Gray 2013a). However, by 26 March 2013 Mr. Paterson, Environment Secretary, acknowledged the futility of eradicating ash dieback disease and shifted his focus to containment: "We know we can't stop Chalara infecting our ash trees so we have to throw our resources into managing it and slowing the spread" (Duffin 2013). He was reported to continue to describe new efforts in this direction, whereby "A quarter of a million ash saplings will be planted as part of a government scheme to find trees resistant to the deadly dieback disease" (ibid.). Mr. Paterson emphasized the significance of such efforts, not only nationally but for the whole of Europe: "This project of monitoring 
250,000 young ash trees is unprecedented in its scope. The UK is leading the way internationally on trying to identify resistant strains" (Duffin 2013). Claire Duffin explained how the young ash saplings will be deliberately exposed to the fungus "and monitored for signs of the disease and any resistance to it" (ibid.). The project was hailed as pioneering; "The projectbelieved to be the first of its kind in Europe-is part of the government's Chalara Management Plan announced yesterday" (ibid.). Towards the end of November and into December 2012, the Telegraph's coverage began to focus more on genetic resistance as the main hope for survival of the ash tree (Guinness 2012; Gray 2012o; Buggs 2012). For instance, the British funding organization, the Biotechnology and Biological Sciences Research Council (BBSRC), decided in March 2013 to support scientific research into ash dieback disease and the genetic makeup of the fungus, awarding large grants to the Sainsbury Laboratory and John Innes Research Centre (e.g., Ford Rojas 2013). This later coverage during March-June 2013 shifted the emphasis away from ground action to fight the disease and firmly towards finding resistance and other scientific solutions. Hope is offered in the form of discovery of two highly resistant trees in Denmark and British as well as Danish scientific collaborations (Gray 2013c).

\section{Policy entrepreneurs}

Findings thus suggest that various government agencies $^{4}$ had themselves assumed great responsibility for raising the spectre of $C$. fraxinea to the agenda of government. The government's Environment Secretary is quoted in a large number of separate articles (Owen Paterson since 2012), and the governmental Forestry Commission staff or actions were quoted or described in about half of the articles written during the time period studied. Closely following these key leading actors in harnessing attention for ash dieback are the two other government agencies in the UK with responsibility for food- and environment-related issues: the Department for Environment, Food and Rural Affairs (Defra), and the Food and Environment

\footnotetext{
$\overline{4}$ No actual changes as a result of the changed political structure or governance structure in response to ash dieback disease were found to have occurred during the time period reviewed in the Daily Telegraph material.
}

Research Agency (Fera), which provides scientific capability and supports policy development. Another stakeholder within the political spectrum who was widely quoted as criticizing the government's response to the disease was the Labour opposition's shadow Environment Secretary, Mary Creagh. Nevertheless, there was obvious attention and activism on the part of the non-profit sector, which held a strong interest in trees and woodland, for example, from the Woodland Trust and the National Trust, and on the part of industry interest organizations, such as the Horticultural Trades Association, the Confederation of Forest Industries and experts from the academic and scientific community regarding the science and ecology of the disease.

\section{Research: surveying and extent mapping}

Early responses were focused on actions to determine the extent of the disease, as well as direct physical destruction of infected samplings. Emergency quarantine measures were issued by the Government's Food and Environment Research Area (Fera) to 90 known customers of the infected nursery saplings where the outbreak was first discovered (Daily Telegraph 2012a). The Forestry Commission also issued a 'pest alert' urging anyone who had imported ashes to check the trees for symptoms (ibid.). In Scotland, forests were closed to public access after discoveries of ash dieback disease (Swinford 2012a), and the National Trust confirmed that ash tree planting on its land was halted (Swinford 2012b). The official strategy in the autumn of 2012, when the scale and stage of $C$. fraxinea was not yet fully known, was destruction through digging up the trees and saplings, burning them or burying them (Gray 2012e). The government destroyed more the 100,000 trees in nurseries around the country during this period (Gray 2012f).

Swinford et al. (2012) reported the Environment Secretary stating in early November that everyone needs to assume their share of the responsibility for preventing disease spread and "make sure they wash their boots, dogs and even children to stop them from inadvertently infecting other areas." At the same time as the general public was asked to report any suspicious infection and the Forestry Commission suspended all ash planting in public forests, very clear voices, such as the Woodland Trust and the 
Horticultural Trade Association (HTA), called for a ban on ash imports (Gray 2012a). Summing up the early responses, the Environment Secretary stated that "we are going to ban imports as soon as we can, as well as impose movement restrictions on trees from infected areas" (Gray 2012b).

\section{Containment attempts/impact minimisation}

Richard Gray reported on the 27 October that an ash import ban would be established, quoting the Environment Secretary: "The plan is to bring a ban on imports on Monday. I have already prepared the legislation and we're ready to go. (...). It will now be illegal to bring in ash trees and move them around" (Gray 2012o). The government also announced that a new website and a new smartphone application would be launched "to help members of the public report signs of Chalara dieback" (ibid.). Another strategy, proposed by the HTA, plant researchers and academics, was to look at forest species composition and "gradually replace native ash trees with resistant species" (Gray $2012 \mathrm{~g}$ ) as well as to "plan for a future without ash" (Gray and Ensor 2012). Gray and Ensor quoted Professor Ian Boyd, who predicted "What we will see is a decline in the ash tree over many, many years. We have got to see that as an opportunity to change the structure of our forests to introduce new species and different forest structures". Richard Gray described how "The Forestry Commission is conducting tests to find varieties of trees that can be used to replace ash" (Gray 2012p). On 6 December 2012, the government announced a strategy for responding to ash dieback disease through the release of the interim Chalara Control Plan. Science Correspondent reported "Owen Paterson, the environment secretary, said the plan 'shows our determination to slow the spread and minimise the impact of Chalara'" (Collins 2012b). He continued "Proposed measures include maintaining a ban on the import and movement of ash trees, investigating genetic traits giving certain trees resistance to the fungus" (ibid.).

Analysis of the government's first written policy response to ash dieback disease, the December 2012 Interim Chalara Action Plan describes how their initial responses were taken: "Following a rapid and extensive survey to establish the extent and distribution of the disease, on 9 November we announced initial actions to tackle the threat to ash trees from Chalara, drawing on scientific advice and the views of a wide range of stakeholders" (Defra 2012a), acknowledging and emphasizing the immediate need for a shared engagement. The document describes the actions taken in the immediate aftermath of learning of $C$. fraxinea's presence, as well as the government's core objectives underpinning their actions, i.e., to: (a) reduce the rate of spread of the disease; (b) develop resistance to the disease in the native ash tree population; (c) encourage landowner, citizen and industry engagement in surveillance, monitoring and action in tackling the problem; (d) build economic and environmental resilience in woodlands and in associated industries (Defra 2012a).

\section{Economic and environmental resilience, and financial} mechanisms

The later Chalara Management Plan, published in March 2013, builds on the interim action plan, but uses a stronger scientific foundation and greater knowledge of disease extent to back up its approach. The plan opens with a clear assessment of why the response must take a broader-than-biology view: "The Government believes the economic and environmental resilience of our forests, wooded areas and other trees, and the associated industries go hand-in-hand. Our trees, woods, forests, hedgerows and landscapes are a vital national asset providing multiple economic, social and environmental benefits" (Defra 2013a).

The main additional responses outlined in the management plan that were not present in the interim action plan pertain to financial mechanisms to help landowner and woodland managers to identify ash dieback disease, remove and dispose of the threat appropriately, and replant with alternative species. These were developed through a number of funding schemes through which government can help the forestry sector and woodland owner/managers to better build-in resilience.

\section{Public engagement}

In general, public engagement is something that marks the responses as well as the specific actions that were identified in relation to the ash crisis in the UK. The Forestry Commission pulled staff off their normal duties to send them out looking for signs of the disease and ordered the tree health experts to inspect ash trees 
at 2300 sites around the country (Daily Telegraph 2012b). Over 500 Forestry Commission staff were redeployed across England, Scotland and Wales to spot evidence of the disease (Gray and Collins 2012). Numerous sites and infected locations were mapped and made publicly available at www.forestry.gov.uk/ chalara (ibid.). A website set up by the University of East Anglia for sightings of infected trees received 450 reports (Gray 2012n) from members of the public, all of which were investigated by plant experts. On 9 November, Fera's Dr. Ward emphasized the key support role members of the public could play in the fight against plant disease, in general, and ash dieback, in particular. Richard Gray reported on 10 February 2013 how actors such as the Woodland Trust have been "attempting to develop an early warning system using observations by members of the public as part of its fight against tree diseases" (Gray 2013a).

A focus on people - the general public, the general media, the environmental sector, and the owners and managers that form the forestry and woodland sector-appears to have played a great role in both the rationale to stimulate action and the implementation of action: "The public response to the threat posed by Chalara has provided a vivid demonstration of just how valued the British ash tree is by woodland and individual tree owners and growers, managers, conservation organisations and members of the public. The Government is committed to tackling the disease through a collaborative approach with stakeholders, and this management plan has benefited from the engagement and expertise of many of them" (Defra 2013a, p. 22). The government further acknowledged this engagement on page 24: "Noteworthy in all the initiatives above has been the positive and proactive involvement of a wide range of industry and nongovernment organisations, who have taken the lead on a number of projects" (Defra 2013a, p. 24).

\section{Discussion}

Analysis of the actions taken and policy responses to the threat posed by ash dieback disease highlights the gap between the biological/plant-science-based perspective on solutions and policymakers' need for policy to manoeuvre between multiple, sometimes disparate, viewpoints and needs. Table 2 summarizes the results. The media content analysis of the Daily
Telegraph material provides, in its entirety, a more multifaceted understanding of the multiple competing factors that policymakers must navigate in their attempts to delineate action, even if individual articles may be written from a single-focus perspective. Many of the actual responses (P6 'other' in Table 2, which were the overwhelming majority) were thus focussed on conducted detailed site surveys and extent mapping, harnessing widespread public engagement, advocating greater border biosecurity and plant paper trails, as well as on physical tree destruction and banning import of ash seedlings. Scientific research capacity needs, as well as organizational and funding structures for disease response, were also stressed by government, as was investigating forest structure adaptations. The governmental and media framing of the issue thus largely differed from the scientific framing, as many of these responses were not considered from the biological perspective (see Table 2 for a quantitative illustration of the discussion of various proposed solutions).

The four main objectives constituting the basis of the government's response strategy (as described in the results section and included in Table 2) do not accord well with the plant-science-based recommendations of, for instance, Pautasso et al. (2013), thus revealing the distance to suggestions such as those in the Montesclaros Declaration. Suggestions framed by the government, and through media coverage, were rather more underpinned by what was framed as realistic and affordable, and by the need for a collaborative, multi-stakeholder approach. The policy responses also emphasize the need for caution and carefully evaluated courses of action due to the scientific uncertainties, partly in recognition of the still evolving biological/environmental/economic implications and partly to protect their actions from critique. Crucially, it could be said that none of Pautasso et al.'s (2013) five plant science-focussed solutions was explicitly adopted by the British Government in its response to ash dieback disease; this is also true of Kirisits et al.'s (2012) recommendations. Instead, the government took a wider view, for instance defining resistance work more broadly than simply "plant breeding" (Pautasso et al. 2013), and focused on cost-effective as well as acceptable/ practicable solutions, particularly given the great public interest and the involvement of multiple stakeholders. 
Table 2 Comparison of suggested and actual government responses with plant-science based recommendations

\begin{tabular}{llc}
\hline Code & $\begin{array}{l}\text { Biological community recommended responses } \\
\text { (Kirisits et al. 2012; Pautasso et al. 2013) }\end{array}$ & $\begin{array}{l}\text { Number of times the action or proposal } \\
\text { was called for or implemented (identified } \\
\text { from the media content and policy } \\
\text { document analysis) }\end{array}$ \\
\hline P1 & Quarantine for ash nursery seedlings & 8 \\
P2 & Avoid planting of ash in forests and landscapes & 3 \\
P3 & Do not remove ash trees from forests & 2 \\
P4 & Breeding for resistance/tolerance & 11 \\
P5 & Inoculum reduction around ancient ash trees & 2 \\
P6 & Other solutions or policies proposed beyond Pautasso et al. & 297 \\
\hline
\end{tabular}

While statements based in plant science identify problems of invasive species largely as a "conservation biology challenge" (Pautasso et al. 2013: 44), the government rather identified the threat from a broader perspective and considered that "Our trees, woods, forests, hedgerows and landscapes are a vital national asset providing multiple economic, social and environmental benefits" (Defra 2013a: 3). In addition there appears to be a gap between these two groups of protagonists in their view of stakeholders and the public. Pautasso et al. (2013: 45), while recognizing the importance of the public, seem to view them as passive recipients of research findings, who should not be unscientifically clouded by emotion. For instance:

Given the key role that local human populations will have in managing this emerging disease, more effort should be made in disseminating the rapidly increasing amount of research results on H. pseudoalbidus, so that the public, foresters and other stakeholders can base their management decisions also on reliable information rather than on emotional responses only.

The government, in contrast, appears to have embraced and harnessed the widespread emotionmotivated response to the ash-dieback threat, transforming that energy into lengthening the arm of governmental response, through citizen monitoring and surveillance efforts and multiple multi-stakeholder initiatives. For instance:

The public response to the threat posed by Chalara has provided a vivid demonstration of just how valued the British ash tree is by woodland and individual tree owners and growers, managers, conservation organisations and members of the public. The Government is committed to tackling the disease through a collaborative approach with stakeholders, and this management plan has benefited from the engagement and expertise of many of them (Defra 2013a, p. 22).

\section{Recommendations/implications}

Findings from the present study suggest that a crucial issue is not only to communicate science to policymakers, but also to develop an understanding of policy making and agenda setting among the science community. The study illustrates that policy problems associated with invasive species cannot be conceived of from a single disciplinary perspective if the aim is to support actual policy processes. In order to comprehend how and why certain decisions are taken or not taken at a political level, it is thus also important to understand the actual political and media framing and agenda-setting dynamics that may influence problem identification and proposals for solutions-and why these may not be in line with proposed problem identifications and solutions coming from the natural sciences. Thus, the social sciences may have a role to play not only in stakeholder reviews or communication of scientific solutions to policy and other actors, but in revealing the institutional and legislative dynamics that influence what actions may be taken on issues such as invasive species. Similarly, climate change is another issue for which the limitations in actions taken so far can be best understood through a focus on institutional social, political and economic 
system dynamics and the ways in which existing decision-making processes and established competing goals may limit or steer action on specific issues.

\section{Conclusion}

The present findings suggest that, overall, the British government's response to $C$. fraxinea, or ash dieback disease, has been broad, multi-stakeholder-based, and incorporated numerous types of concerns expressed by multiple actors. Government actions did have a strong undertone of influence from, and concern for, economic and industry (including small ash-based businesses) perspectives. On the policy side, the government is quite explicit about why it took, or did not take, certain courses of action, with much of the decision-making being influenced by epidemiological-biogeographical modelling of disease scenarios and implications, but also by a detailed cost-benefit analysis of proposed interventions and legislative practicality. In light of the findings revealed by the present agenda-setting and media content analysis methodology, and in the presence of extremely strong interest and engagement on the part of the general public, Pautasso et al.'s (2013) and Kirsits et al.'s (2012) proposed action points for tackling ash dieback disease read as being somewhat separate from an understanding of agenda-setting processes and the policy-making arena, and as being too narrowly rooted in the biological discipline. An improved understanding on the part of the natural science disciplines of the factors influencing policy action is essential to moving policy support towards a more effective and integrated response to biological threats in the policy community.

Acknowledgements We are grateful to Paul Watson for research assistance and to Future Forests, a research programme funded by the Swedish Foundation for Strategic Environmental Research MISTRA, the Swedish University of Agricultural Sciences and Umeå University, for funding.

Open Access This article is distributed under the terms of the Creative Commons Attribution 4.0 International License (http:// creativecommons.org/licenses/by/4.0/), which permits unrestricted use, distribution, and reproduction in any medium, provided you give appropriate credit to the original author(s) and the source, provide a link to the Creative Commons license, and indicate if changes were made.

\section{References}

Bakys R, Vasaitis R, Barklund P, Thomsen IM, Stenlid J (2009) Occurrence and pathogenicity of fungi in necrotic and nonsymptomatic shoots of declining common ash (Fraxinus excelsior) in Sweden. Eur J For Res 128(1):51-60

Baumgartner FR, Jones B (1993) Agendas and instability in American politics. University of Chicago Press, Chicago

Birkland TA (1998) Focusing events, mobilization, and agendasetting. J Public Policy 18(1):53-74

Buggs R (2012) British woodlands need diversity from around the world. Daily Telegraph, Earth Comment. http://www. telegraph.co.uk/earth/earthcomment/9732128/Britishwoodlands-need-diversity-from-around-the-world.html 8:40 AM GMT 09 Dec 2012

Chong D, Druckman JN (2007) Framing theory. Annu Rev Polit Sci 10:103-126

Collins, N. (2012a) Ash dieback response delayed due to other outbreaks. Daily Telegraph, Environment Section, Forests. http://www.telegraph.co.uk/earth/environment/forests/ 9738201/Ash-dieback-response-delayed-due-to-otheroutbreaks.html 6:12 PM GMT 11 Dec 2012

Collins N (2012b) British landscape ‘being surrendered' by ash dieback failures. Daily Telegraphy, Environment Section. http://www.telegraph.co.uk/earth/environment/forests/ 9727478/British-landscape-being-surrendered-by-ashdieback-failures.html 4:12 PM GMT 06 Dec 2012

Collins N (2012c) British scientists appeal to world for Ash dieback help. Daily Telegraph, Earth News, Environment Section, Forestry. http://www.telegraph.co.uk/earth/ environment/forests/9743491/British-scientists-appeal-toworld-for-Ash-dieback-help.html 12:01 AM GMT 14 Dec 2012

Council Directive 2000/29/EC of 8 May 2000 on protective measures against the introduction into the community of organisms harmful to plants or plant products and against their spread within the Community. Off J Eur Union

D'Angelo P, Kuypers JA (2010) Introduction. Doing news framing analysis. In: D’Angelo P, Kuypers JA (eds) Doing news framing analysis. Empirical and theoretical perspectives. Routledge, New York, pp 1-14

Daily Telegraph (2012a) Disease threatens Britain's ash trees for first time, Newspaper article. http://www.telegraph.co. uk/news/earth/countryside/9319741/Disease-threatensBritains-ash-trees-for-first-time.html 7:00AM BST 09 Jun 2012. Accessed 5 Nov 2014

Daily Telegraph (2012b) Ash die back disease could have been lurking in UK for years,Newspaper article. http://www. telegraph.co.uk/earth/countryside/9638359/Ash-die-backdisease-could-have-been-lurking-in-UK-for-years.html 7:00AM GMT 28 Oct 2012. Accessed 5 Nov 2014

Daily Telegraph (2013) Ash dieback: native trees coming into Britain will have to show complete 'paper trail'. Daily Telegraph, Earth News, Environment Section. http://www. telegraph.co.uk/earth/environment/9806392/Ash-diebacknative-trees-coming-into-Britain-will-have-to-showcomplete-paper-trail.html 16 Jan 2013

Defra (2012a) Interim Chalara control plan. Department for Environment, Food and Rural Affairs. Publication number: PB13843. https://www.gov.uk/government/uploads/system/ 
uploads/attachment_data/file/69620/pb13843-chalara-controlplan-121206.pdf. Accessed 04 Nov 2013

Defra (2012b) Ash disease found in Somerset. Department for Environment, Food and Rural Affairs. https://www.gov. uk/government/news/ash-disease-found-in-somerset.

Accessed 04 Nov 2013

Defra (2012c) Ash disease found in Dorset. Department for Environment, Food and Rural Affairs Located at: https:// www.gov.uk/government/news/ash-disease-found-indorset. Accessed 04 Nov 2013

Defra (2012d) Ash disease found in East Sussex. Department for Environment, Food and Rural Affairs. https://www.gov. uk/government/news/ash-disease-found-in-east-sussex. Accessed 04 Nov 2013

Defra (2012e) New public body will protect forests for future generations. Department for Environment, Food and Rural Affairs. https://www.gov.uk/government/news/new-publicbody-will-protect-forests-for-future-generations. Accessed 04 Nov 2013

Defra (2013a) Chalara management plan. Department for Environment, Food and Rural Affairs. Publication number: PB 13936. https://www.gov.uk/government/uploads/system/ uploads/attachment_data/file/221051/pb13936-chalara-manage ment-plan-201303.pdf. Accessed 04 Nov 2013

Defra (2013b) Chalara in ash trees: a framework for assessing ecosystem impacts and appraising options. Department for Environment, Food and Rural Affairs. https://www.gov. uk/government/uploads/system/uploads/attachment_data/ file/200396/pb13906-chalara-socio-economic-framework. pdf. Accessed 04 Nov 2013

Duffin C (2013) £1.5m search for trees resistant to ash dieback. Daily Telegraph, Earth News, Environment Section. http:// www.telegraph.co.uk/earth/environment/9954908/1.5msearch-for-trees-resistant-to-ash-dieback.html 2:30 PM GMT 26 Mar 2013

Eustis JD (2000) Agenda-setting. The universal service case. Dissertation in Environmental Design and Planning, Faculty of Virginia Polytechnic Institute and State University, Blacksburg, Virginia

Farley J, Baker D, Batker D, Koliba C, Matteson R, Mills R, Pittman J (2008) Opening the policy window for ecological economics: Katrina as a focusing event. Ecol Econ 63:344-354

Fifer N, Orr SK (2013) The influence of problem definitions on environmental policy change: a comparative study of the yellowstone wildfires. Policy Stud J 41:636-653

Ford Rojas J-P (2013) Woodland devastated by ash dieback could be restored by finding resistant trees. Daily Telegraph, Gardening Section. http://www.telegraph.co.uk/ gardening/plants/trees/9917160/Woodland-devastated-byash-dieback-could-be-restored-by-finding-resistant-trees. html 9:37 AM GMT 08 Mar 2013

Gray L (2012a) Deadly fungus in ash trees could be 'next Dutch elm disease warns Woodland Trust. Daily Telegraph, Earth News Section. http://www.telegraph.co.uk/earth/earth news/9566224/Deadly-fungus-in-Ash-trees-could-be-nextDutch-elm-disease-warns-Woodland-Trust.html 26 Sep 2012

Gray L (2012b) Alan Titchmarsh says Tories losing connection with countryside. Daily Telegraph, Gardening Section. http://www.telegraph.co.uk/gardening/9711944/AlanTitchmarsh-says-Tories-losing-connection-with-country side.html 6:30 AM GMT 30 Nov 2012
Gray L (2012c) Ash dieback came after tree disease already at record high. Daily Telegraph, Earth News. http://www. telegraph.co.uk/earth/earthnews/9678776/Ash-diebackcame-after-tree-disease-already-at-record-high.html 7:00 AM GMT 15 Nov 2012

Gray L (2012d) Ash dieback mistaken for 'squirrel damage'. Daily Telegraph, Earth News. http://www.telegraph.co.uk/ earth/earthnews/9699330/Ash-dieback-mistaken-for-squirreldamage.html 7:00 AM GMT 24 Nov 2012

Gray L (2012e) Ash dieback one of ten 'epidemic' tree pests and diseases. Daily Telegraph, Earth News. http://www.tele graph.co.uk/earth/earthnews/9704055/Ash-dieback-one-often-epidemic-tree-pests-and-diseases.html 7:04 PM GMT 26 Nov 2012

Gray L (2012f) Ash dieback will 'inevitably' get to historical collection at Kew. Daily Telegraph, Earth News. http:// www.telegraph.co.uk/earth/earthnews/9661124/Ash-die back-will-inevitably-get-to-historical-collection-at-Kew.html 12:36 PM 07 Nov 2012

Gray L (2012g) Ash dieback: no point in chopping trees down.Daily Telegraph. Earth News. http://www.telegraph. co.uk/earth/earthnews/9664414/Ash-dieback-No-point-inchopping-trees-down.html 2:54 PM 08 Nov 2012

Gray L (2012h) Could the privet hedge be spreading ash dieback? Daily Telegraph, Earth News. http://www.telegraph. co.uk/earth/earthnews/9670462/Could-the-privet-hedge-bespreading-ash-dieback.html Accessed 11 pm, 11 Nov 2012

Gray L (2012i) Do imports for 'instant gardening' drive tree disease? Daily Telegraph, Earth News. http://www.tele graph.co.uk/earth/earthnews/9675723/Do-imports-for-instantgardening-drive-tree-disease.html 7:00 AM GMT 14 Nov 2012

Gray L (2012j) Gardeners sold 'native' ash trees grown abroad. Daily Telegraph, Earth News. http://www.telegraph.co.uk/ earth/earthnews/9649565/Gardeners-sold-native-ash-treesgrown-abroad.html 11:00 PM 01 Nov 2012

Gray L (2012k) Gardeners urged to buy British to stop tree disease. Daily Telegraph, Earth News. http://www.tele graph.co.uk/earth/earthnews/9670324/Gardeners-urged-tobuy-British-to-stop-tree-disease.html 7:00 AM GMT 12 Nov 2012

Gray L (20121) Imports of ash trees to be banned-but is it too late? Daily Telegraph, Earth News. http://www.telegraph. co.uk/earth/earthnews/9632725/Imports-of-ash-trees-tobe-banned-but-is-it-too-late.html 25 Oct 2012

Gray R (2012m) American ash trees could protect British woodlands. Daily Telegraph, Environment Section. http:// www.telegraph.co.uk/earth/environment/forests/9731769/ American-ash-trees-could-protect-British-woodlands.html 8:20 AM GMT 09 Dec 2012

Gray R (2012n) Ash dieback disease suspected in private gardens for first time. Daily Telegraph, Earth News, Countryside Section. http://www.telegraph.co.uk/earth/country side/9685153/Ash-dieback-disease-suspected-in-privategardens-for-first-time.html 9:00 PM GMT 17 Nov 2012

Gray R (2012o) Ash tree import ban to halt spread of disease. Daily Telegraph, Earth, Countryside Section. http://www. telegraph.co.uk/earth/countryside/9637528/Ash-tree-importban-to-halt-spread-of-disease.html 27 Oct 2012

Gray L (2013a) English forests 'safe' from being sold off-but what about funding? Daily Telegraph, Earth News. http:// 
www.telegraph.co.uk/earth/earthnews/9839695/Englishforests-safe-from-being-sold-off-but-what-about-funding. html 4:27 PM GMT 31 Jan 2013

Gray L (2013b) Government ash dieback 'management plan' criticised for failing to stop disease. Daily Telegraph, Earth News. http://www.telegraph.co.uk/earth/earthnews/99484 11/Government-ash-dieback-management-plan-criticisedfor-failing-to-stop-disease.html 7:00 AM GMT 26 Mar 2013

Gray R (2013c) Ash dieback found in three new sites in first infections of the year. Daily Telegraph, Earth News, Environment Section. http://www.telegraph.co.uk/earth/ environment/9904591/Ash-dieback-found-in-three-newsites-in-first-infections-of-the-year.html 7:30AM GMT 03 Mar 2013

Gray L, Collins N (2012) More than 500 inspecting woodland every day for ash dieback-but is it "too little too late"? Daily Telegraph, Earth News. http://www.telegraph.co.uk/ earth/9654377/More-than-500-inspecting-woodland-everyday-for-ash-dieback-but-is-it-too-little-too-late.html $\quad 8: 58$ PM 04 Nov 2012

Gray R, Ensor J (2012) Gardeners told to burn fallen ash leaves. Daily Telegraph, Earth, Countryside Section. http://www. telegraph.co.uk/earth/countryside/9669487/Gardeners-told-toburn-fallen-ash-leaves.html 9:00 PM 10 Nov 2012

Greer G (2012) Germaine Greer: don't panic about ash dieback. Look at the science. Daily Telegraph, Earth Section. http:// www.telegraph.co.uk/earth/9684133/Germaine-Greer-Dontpanic-about-ash-dieback.-Look-at-the-science.html 5:52 PM GMT 16 Nov 2012

Guinness B (2012) Bunny Guinness: the ash crisis shows it's time to rethink Britain's quarantine controls. Daily Telegraph, Gardening Section. http://www.telegraph.co.uk/gard ening/9691738/Bunny-Guinness-The-ash-crisis-shows-itstime-to-rethink-Britains-quarantine-controls.html 7:37 PM GMT 20 Nov 2012

Hantula J, Müller MM, Uusivuori J (2014) Short communication International plant trade associated risks: laissezfaire or novel solutions. Environ Sci Policy 37:158-160

Henstra D (2010) Explaining local policy choices: a multiple streams analysis of municipal emergency management. Can Public Adm 53(2):241-258

Hough A (2012) Ash dieback will never be completely eradicated from UK's trees. Daily Telegraph, Earth News. http:// www.telegraph.co.uk/earth/earthnews/9666729/Ashdieback-will-never-be-completely-eradicated-fromUKs-trees.html 12:30 PM GMT 09 Nov 2012

IPCC (2014) Climate change 2014: impacts, adaptation, and vulnerability. Part A: global and sectoral aspects. In: Field CB, Barros VR, Dokken DJ, Mach KJ, Mastrandrea MD, Bilir TE, Chatterjee M, Ebi KL, Estrada YO, Genova RC, Girma B, Kissel ES, Levy AN, MacCracken S, Mastrandrea PR, White LL (eds) Contribution of working group ii to the fifth assessment report of the intergovernmental panel on climate change. Cambridge University Press, Cambridge

Kingdon JW (1995) Agendas, alternatives and public policies, 2nd edn. HarperCollins, New York

Kirisits T, Kritsch P, Kraeutler K, Matlakova M, Halmschlager E (2012) Ash dieback associated with Hymenoscyphus pseudoalbidus in forest nurseries in Austria. J Agric Ext Rural Dev 4(9):230-235

Lean G (2012) Ash dieback disease: the race is on to stop the rot. http://www.telegraph.co.uk/earth/countryside/9636010/ Ash-dieback-disease-the-race-is-on-to-stop-the-rot.html. Daily Telegraph (earth news/countryside). 26 Oct 2012

López-Santana M (2006) The domestic implications of European soft law: framing and transmitting change in employment policy. J Eur Public Policy 13(4):481-499

Lukka K, Modell S (2010) Validation in interpretive management accounting research. Acc Organ Soc 35(4):462-477

MacLeod A, Pautasso M, Jeger MJ, Haines-Young R (2010) Evolution of the international regulation of plant pest and challenges for future plant health. Food Secur 2:49-70

Mason R (2012) Diseased ash trees 'may have entered UK after officials found first case. http://www.telegraph.co.uk/ news/politics/9641146/Diseased-ash-trees-may-haveentered-UK-after-officials-found-first-case.html Political Correspondent, Daily Telegraph 29 Oct 2012

Matthes J (2009) What's in a frame? A content analysis of media framing studies in the world's leading communication journals, 1990-2005. Journal Mass Commun Q 86(2):349367

Montesclaros (2011) The Montesclaros Declaration. Declaration from the participants of the International Union of Forest Research Organizations meeting held at the Montesclaros Monastery in Cantabria, Spain. May 23th-27th, 2011

Moreton C (2012) Ash dieback: the ruined Polish forest where deadly fungus began. Daily Telegraph, World News, Europe Section. http://www.telegraph.co.uk/news/worldnews/ europe/poland/9669165/Ash-dieback-the-ruined-Polishforest-where-deadly-fungus-began.html 8:00 AM GMT 11 Nov 2012

Olsson E-K (2009) Responsibility framing in a "climate change induced' compounded crisis: facing tragic choices in the Murray-Darling Basin. Environ Hazards 8(3):226-240

Pautasso M, Döring TF, Garbelotto M, Pellis L, Jeger MJ (2012) Impacts of climate change on plant diseases-opinions and trends. Eur J Plant Pathol. doi:10.1007/s10658-012-9936-1

Pautasso M, Aas G, Queloz V, Holdenrieder O (2013) European ash (Fraxinus excelsior) dieback-a conservation biology challenge. Biol Conserv 158:37-49

Pettersson M, Strömberg C, Keskitalo ECH (2016) Possibility to implement invasive species control in Swedish forests. Ambio 45(2):214-222

Reese SD (2007) The framing project: a bridging model for media research revisited. J Commun 57:148-154

Rowley T (2012) Trees that thrive amid killer fungus hold secret to saving threatened ash. Daily Telegraph, Earth News. http://www.telegraph.co.uk/earth/9652599/Trees-that-thriveamid-killer-fungus-hold-secret-to-saving-threatened-ash.html 10:29 PM 02 Nov 2012

Santini A et al (2013) Biogeographical patterns and determinants of invasion by forest pathogens in Europe. N Phytol 197(1):238-250

Soroka SN (2002) Agenda-setting dynamics in Canada. UBC Press, Vancouver

Swinford S (2012a) Ash dieback: what to look out for. Daily Telegraph, Earth News. http://www.telegraph.co.uk/earth/ 
9643794/Ash-dieback-What-to-look-out-for.html. 5:10 PM GMT 30 Oct 2012

Swinford S (2012b) National Trust checks 300-year-old ash trees for disease. Daily Telegraph, Earth News Article. http://www.telegraph.co.uk/earth/9643656/National-

Trust-checks-300-year-old-ash-trees-for-disease.html 4:03 PM GMT 30 Oct 2012

Swinford S (2012c) Woodland walking ban as ash disease takes hold. Daily Telegraph, Earth News Article. http://www. telegraph.co.uk/earth/9643287/Woodland-walking-banas-ash-disease-takes-hold.html 30 Oct 2012

Swinford S, Gray L, Rowley T (2012) Wash children to stop ash fungus, minister says. Daily Telegraph, Earth News. http:// www.telegraph.co.uk/earth/earthnews/9652270/Wash-childrento-stop-ash-fungus-minister-says.html 2 Nov 2012
The National Archives (2012) The Plant Health (Forestry) (Amendment) Order 2012. http://www.legislation.gov.uk/ uksi/2012/2707/contents/made. Accessed 04 Nov 2013

Timmermann V, Børja I, Hietala AM, Kirisits T, Solheim H (2011) Ash dieback: pathogen spread and diurnal patterns of ascospore dispersal, with special emphasis on Norway. EPPO Bull 41:14-20. doi:10.1111/j.1365-2338.2010.02429

UK Government (2012) Action on ash tree disease Chalara (9th November 2012). https://www.gov.uk/government/news/ action-on-ash-tree-disease-chalara. Accessed 04 Nov 2013

Weaver DH (2007) Thoughts on agenda setting, framing and priming. J Commun 57:142-147

Zhou Y, Moy P (2007) Parsing framing processes: the interplay between online public opinion and media coverage. J Commun 57:79-98 